\title{
Development of students' leadership competencies: a case of summer schools
}

\author{
Veronika Smirnova \\ Russian State Academy of Intellectual Property (RGIIS) \\ 6 Miklukho-Maklaja Street, 117279, Moscow \\ Russian Federation \\ e-mail: ikar1@yandex.ru \\ Yuliya Vasileva \\ Russian State Academy of Intellectual Property (RGIIS) \\ 6 Miklukho-Maklaja Street, 117279, Moscow \\ Russian Federation \\ e-mail: ikar1@yandex.ru \\ Anna Sardarian \\ Management Department, Economics Faculty, \\ Peoples' Friendship University of Russia (RUDN University) \\ 6 Miklukho-Maklaja Street, 117279, Moscow \\ VINITI RAN \\ 20 Usievicha Street, 125190, Moscow \\ Russian Federation \\ e-mail: sardaryan_ar@pfur.ru
}

\begin{abstract}
Our paper focuses on summer schools as a tool of building leader's competencies, intelligent and creative abilities in present-day students of higher vocational school. It deals with main concepts of summer schools based on the study of issue-related publications, presents the most complete and extended classification of summer schools, and analyzes them in the educational services market in a number of countries of the world. The paper investigates summer schools, both from those operating on a multidisciplinary basis and those specialized ones in Russia, CIS countries, and some well-known summer leadership schools in the global educational services market.

This paper is based on the classifications of summer schools presented in modern academic and practical literature. Moreover, the paper presents the findings of our own unique survey on young people's perception of a modern leader. It also substantiates the role of summer schools in the development of leadership skills and qualities in young people according to the concept of continuous education (i.e. life-long learning).
\end{abstract}

\section{Introduction}

In recent years the business education market witnesses the promotion of applied programs, practical trainings on improving leadership skills and teaching leadership behavior, as well the establishment of new centers for studying this phenomenon. The issues of developing leadership capabilities in students is getting more and more popular in the academic community, more and more leadership programs are opening not only at advanced universities of North America and Europe, but also in Russian and in the former Soviet republics. In the context of life long learning summer educational programs, or summer schools, are of a particular importance. Thus, we can observe a growing interest in this subject in recent years. Summer schools are especially popular with young generation, including higher educational institution students.

In modern academic literature, few works focusing on this topic consider the essence and peculiarities of summer schools' operations. Thence, Krasnova (2012) studied summer schools as an area of educational tourism while Komarova (2015) and Schneider (2017) describe them as an instrument for university internationalization. Technological aspects of organizing summer schools were studied by Nazarova (2017) or Parfenova (2015). Hands-on experience and the analyses of summer schools' operation in Russia and other countries of the world are considered in the works by Mamedov (2011), Kashina (2013), Baranova and Borsheva (2016). Summer schools as a tool for developing complementary competences have been examined in the works by Naumkin et al. (2012). However, the influence of summer schools on the leadership qualities and skills of young people are hardly presented in contemporary authors' works. 
Leader qualities were first studied by such well-known scholars as Stogdill (1974), Mann (1959), Bennis (1989). Among modern researchers of leadership characteristics, we distinguish Goleman et al. (2002), Cooper (2007), Lazányi et al. (2017), or Bendas (2017). These works present both theoretical issues of researching leadership, including modern young leaders, and practical aspects: tools and methods for developing leadership qualities, the role of various factors in the process of developing leadership competencies. Nevertheless, these authors have not studied summer schools as a factor influencing the development of these competences. These and other aspects explain the choice of research topic and the urgency of studying further the role of summer schools as an effective tool in enhancing the leadership competencies of young people.

\section{The essence of summer school as an educational technology}

A summer school is a relatively new educational technology, representing a group of short-term educational programs, which are usually offered in the summer for students at secondary and higher educational institutions. In Russia, the first summer schools were organized more than 50 years ago and implemented in the form of physico-mathematical camps for schoolchildren. However, summer schools in their current form emerged in Russia relatively recently.

Summer schools of higher educational institutions are an element of life long learning, a career component and the form of organizing spare time; they facilitate the acquisition of new knowledge, skills, competences in basic and other specialties, develop interdisciplinary links (Nazarova 2017). Moreover, summer schools allow expanding research competence, skills of practical work, shape the students' adaptability to different cultural environments and differences in organizational cultures of modern companies, develop communication skills through creating a platform for communication and working in a team for young people. In summer schools, as a rule, the training process relies on hands-on experience: with the help of a specially developed series of cognitive games and exercises learners acquire such skills and competencies as strategic thinking, intercultural communication, leadership, teamwork, self-motivation, etc. Among the teaching instruments used in summer schools there are: role plays, round tables, project work, discussions, seminars, teamwork, field work, expeditions, case studies, workshops, trainings, meetings with famous people, conferences, visits to various centers and enterprises. In addition, the program of summer schools includes various cultural events (tours, participation in concerts, etc.)

Thus, summer scientific schools for students allow modeling a quasi-professional innovation environment and realizing practically all modern methodological approaches and pedagogical technologies that ensure the formation of students' competence in innovation (Naumkin 2012) and the ability to form leadership skills. In terms of benefits for universities, the summer school is an instrument of promoting the university brand; it forms a positive image of the educational institution in the global educational space, strengthens the internationalization of the university, etc. Thus, establishing summer schools should be one of the most important activities in both academic and extra-curricular areas of modern institutions of higher professional education.

\section{Classification of summer schools in the education market}

In the modern academic literature one can find various classifications of summer schools reflecting their modern diversity in the global educational services market. All summer schools, as a rule, are subdivided into short-term and long-term, specialized and multi-disciplinary. We propose the most complete, complex classification of summer schools (Table 1).

Table 1. Summer schools' classification

\begin{tabular}{|l|l|l|}
\hline No. & \multicolumn{1}{|c|}{ Classification basis } & \multicolumn{1}{c|}{ Types of summer schools } \\
\hline 1 & Duration & Short term (some days), long term (some weeks) \\
\hline 2 & Tuition & fee-paying or free of charge \\
\hline 3 & Type of attendance & Permanent residence, short-term visit during the day \\
\hline 4 & Regularity of schools & One-off, cyclical (every year) \\
\hline 5 & Training profile & $\begin{array}{l}\text { Specialized (one specialty) and multidisciplinary (language, } \\
\text { creative, sports, computer, informative) }\end{array}$ \\
\hline 6 & Age of participants & Junior school children, teenagers, university students \\
\hline 7 & Integration degree & Integrated into curriculum, not integrated \\
\hline 8 & Status & National, international \\
\hline 9 & Number of participants & Small groups, large groups \\
\hline 10 & Academic content & Fundamental, applied (practical), combined \\
\hline & & Source: Own results \\
\hline
\end{tabular}


For example, multi-disciplinary schools bring together young people of different interests, education level, and might lead to the increase of personal competencies crucial for future employment (Bordean and Sonea 2018). Specialty schools enroll more homogeneous group of students: schoolchildren and students with high academic performance or those who are interested in a particular field (e.g. sport, culture, foreign languages etc.) At applied summer schools, students participate in the implementation of specific projects, visit enterprises and meet with business practitioners. Fundamental school are aimed at delivering the information in a theoretical format in the form of lectures, seminars, the performance of individual independent assignments. At summer schools whose programs are integrated into the curriculum the examinations results upon completing summer school training are taken into account in the general curriculum of the students.

\section{The practice of implementing summer schools in the modern education market}

The active development of summer schools in the countries of the world fell on the past decades. The greatest number of them was organized in North America and Western Europe. Finland, Germany, and the Netherlands stand out among other European countries in terms of the number of summer schools. The most popular educational programs for summer schools in Europe are international relations, political science, cultural studies, jurisprudence, foreign languages, physics, mathematics and computer science. The site https://gradstudyabroad.ru demonstrates the offers of European summer schools (Figure 1).

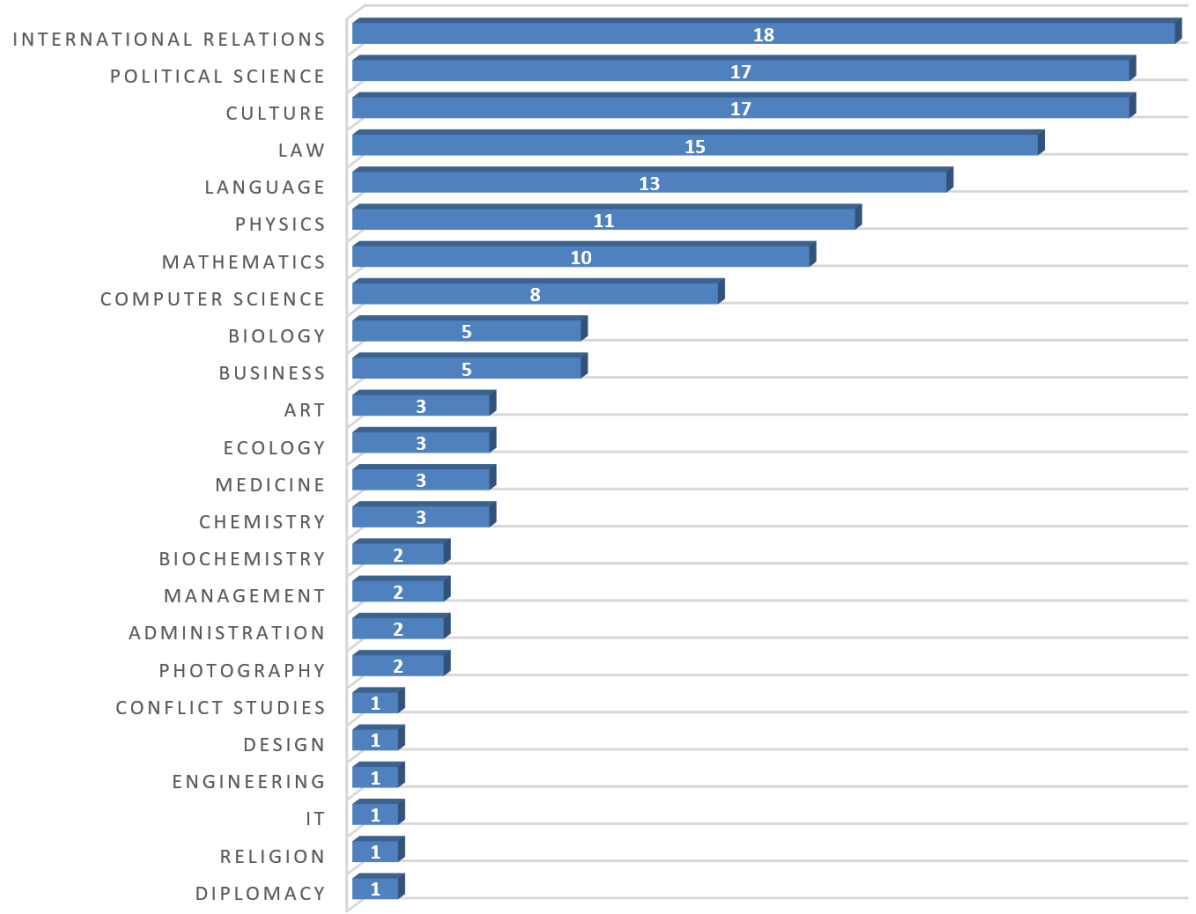

Fig. 1. The main educational programs at European summer schools Source: Own results

One of the specific features of the European summer schools, which distinguishes them from the Russian ones, is their full integration into the educational process. For example, students attending a summer school gain a certain amount of credits within the framework of the Bologna Process. Often, these credits are given in advance to students who build up some reserve for further education at universities.

In Russia and CIS countries the most popular summer schools are language schools, however in recent years career guidance, sports, tourism, and schools aimed at developing leadership qualities are being set up. Nevertheless, the latter are only single projects (Table 2).

In Russia, the most popular multi-disciplinary summer school is the Summer Ecological School with programs on biology, physics, and mathematics. Moreover, school participants can attend courses in various subjects. Specialized summer schools are also actively developing. WIPO's specialized Summer School is widely known, which is annually organized by the Federal Intellectual Property Service (Rospatent) and the Russian State Academy of Intellectual Property (RSAIP). The program of the Summer School is designed for graduate students of Master'w degree and postgraduate training programs, as well as specialists in any fields of experience. On completing the summer school students are given the certificate on behalf of the World Intellectual Property Organization (WIPO). 
Table 2. Educational summer schools in CIS countries

\begin{tabular}{|c|l|c|}
\hline No. & \multicolumn{1}{|c|}{ Name: } & Country \\
\hline 1 & Mobile tourist training camp "Vertical” & Kazakhstan \\
\hline 2 & Education project "Republic of Evergreen" in the format of 12-day summer school. & Kazakhstan \\
\hline 3 & Language summer school "Hilton" & Kazakhstan \\
\hline 4 & $\begin{array}{l}\text { A number of educational programs JUST DILIJAN IT! on natural sciences and } \\
\text { humanitarian disciplines - foreign language, art, architecture, literature, theater, and } \\
\text { also entrepreneurship. }\end{array}$ & Armenia \\
\hline 5 & $\begin{array}{l}\text { Dreamcamp - a camp that organizes entertainment, educational and career guidance } \\
\text { programs for children and teenagers. }\end{array}$ & Belarus \\
\hline 6 & Educational summer school "Eureka!” & Moldova \\
\hline 7 & Summer school "Summer educational camp focusing on environment" & Tajikistan \\
\hline 8 & HAPPY SUMMER - Summer school of intellectual development & Tajikistan \\
\hline
\end{tabular}

Practical seminars, lectures and business games are conducted by experts of WIPO, Rospatent, leading lecturers of RSAIP, SSU, and visiting scholars. In Russia Saint Petersburg Polytechnic University, Novosibirsk State University, St. Petersburg State University offer the greatest number of programs at summer schools (Figure 2).
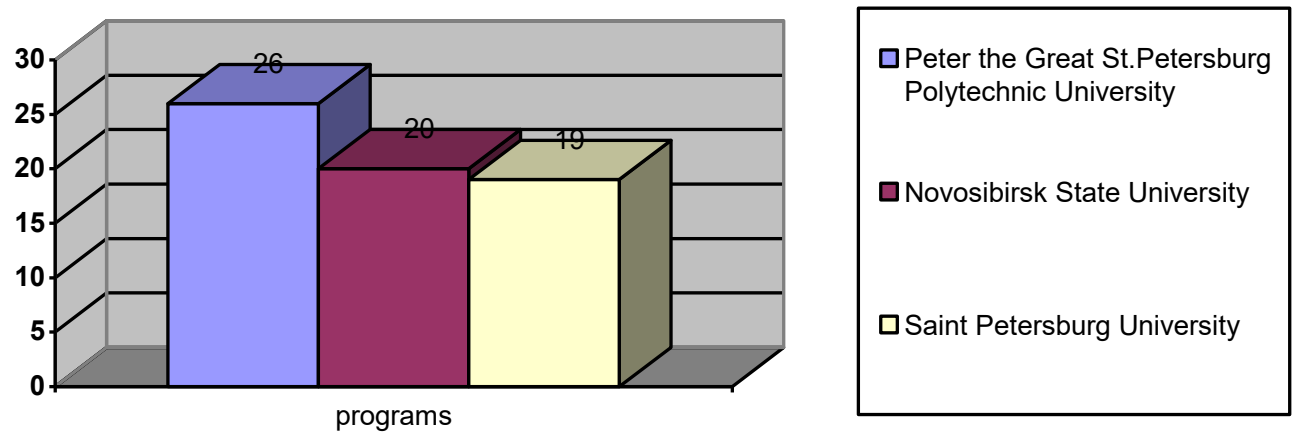

Fig. 2. Russian universities with the largest number of programs at summer schools Source: Own results

\section{Leadership summer schools in the global education market}

There are so far few speciality summer schools in the field of leadership in the world educational services market. One of such schools not only in North America, but also in the world is the Hansen Summer Institute on Leadership and International Cooperation (USA, San Diego). The school provides participants with a unique experience in leadership and international cooperation, designed for three weeks. In the course of its implementation, they use such educational technologies as in-class learning (lectures and seminars), hands-on training (business cases, role-playing games on multicultural management, conflict resolution and teamwork). Since the school is financed by the Fred J. Hansen Foundation, the organizers cover all expenses for students (travel costs, accommodation, meals, educational materials, etc.) However, the requirements for candidates in the selection process for this school are quite serious: those who want to join the course has to prove their leadership capability, have experience in public works (for example, volunteer movements, nongovernmental organizations, etc.) and have a good command of English. (Hansen 2018)

Another well-known summer school designed for developing leadership competencies among teenagers aged 14-18 is the Stanford University Summer School in the USA. In the process of three-week training at this school, the students develop such leadership skills and qualities as: critical and creative thinking, publicspeaking skills, the ability to manage conflicts, teamwork and decision-making skills, etc. The tuition at this school is 7800 thousand dollars. (Stanford University)

In Russia, specialty summer schools for developing leadership are represented by such individual programs as: Leadership schools "Molodye Vetra" (Young Winds), "Zvezdy" (Stars), "Spektr" (Spectrum), School of Leadership and Self-Development (SLS). However, these schools are organized outside the institutions of higher professional education and, most often, are aimed at teaching students of the senior grades of general education schools. 


\section{$6 \quad$ Required qualities and competences of a modern leader}

For many years, researchers in the fields of management sciences, sociology, political science and psychology have tried to depict the "portrait of the leader" - to distinguish a typical characteristic of the leader, a certain set of qualities that would describe an individual with leadership skills and personal characteristics. However, numerous studies carried out in this field so far have not identified a unified system of leadership qualities. However, the representatives of both business and academic community (teachers and university management) as well younger generation consider that typical leaders are characterized by such qualities as: confidence, public-speaking ability, ability to make decisions, energy, high level of intelligence.

Thus, it seems interesting to cite some findings of the survey (conducted in 2015-2016 by one of this article's authors) of more than 200 students of the Economics Faculty, RUDN University on the leadership and qualities of the modern leader, which showed that according to nowaday students the most striking features of the leader are: self-confidence (86\%), independence (76\%), public-speaking ability (62\%), riskiness (51\%) and sense of humor $(49 \%)$ (Figure 3).
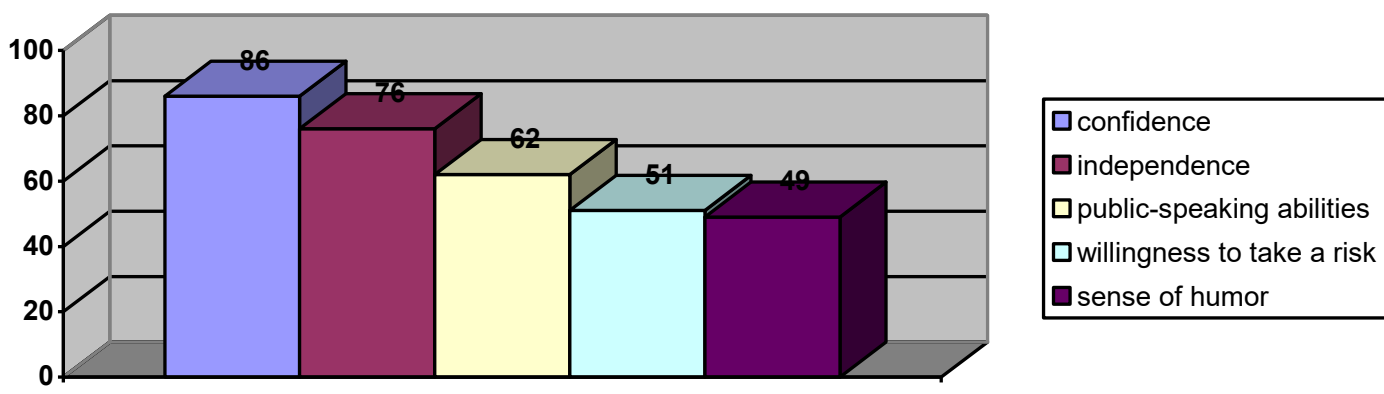

Fig. 3. The most important leader's qualities in students' perception

Source: compiled by the authors on the basis of management students' survey, the Economics Faculty, RUDN University, 2015-2016.

Among the least essential features of the leader respondents named diplomacy (6\%), adaptability (8\%), ability to understand people (10\%), sympathy (empathy) (11\%) (Fig. 4). High level of intelligence as a necessary quality of the leader was chosen by $32 \%$ of respondents, energy - 35\%, composure (23\%), good intuition - $17 \%$, and sociability $-15 \%$.

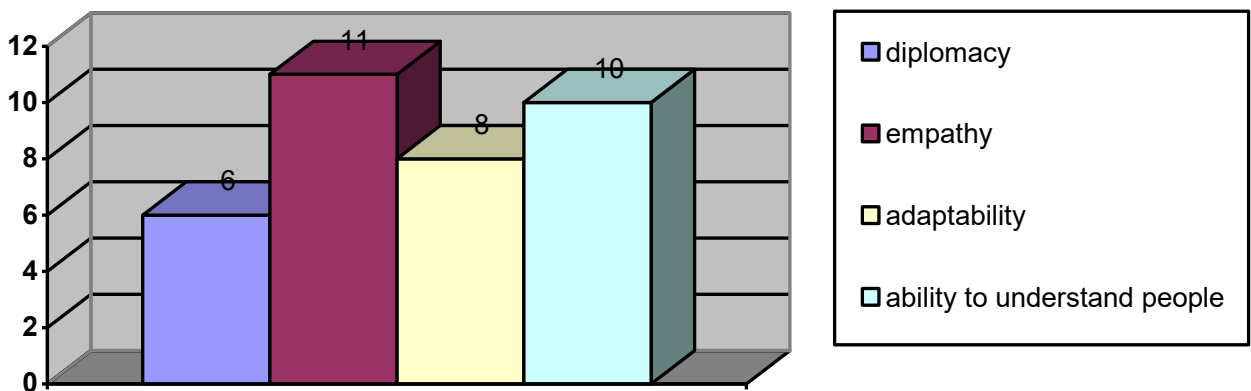

Fig. 4. The most important leader's qualities in students' perception Source: Own results

Thus, the findings of the survey on the perception of the modern leader among students of institutions of higher education and leadership researchers are quite similar, which suggests that in modern society there is a clear understanding of the leader, his/her main characteristic qualities and skills. This understanding contributes to achieving the greatest effectiveness in the organization and conduct of summer schools, the development of leadership skills and competencies in young people.

\section{Conclusions}

Overall, the qualities given to the leader by both representatives of modern youth, and researchers of leadership issues from the point of view of psychology, sociology and management sciences, can be developed through 
regular trainings, including in the process of continuous learning (life-long learning). One of the tools used in the process of life long learning is the summer schools, participation in which can be aimed at increasing certain competencies, including leadership.

Since the popularity of leadership today is steadily growing both among business representatives and university students, the organization of such schools is one of the promising means in the development of institutions of higher vocational education. Speciality schools is intended to develop leadership competences and promote the training of highly-qualified specialists capable to adapt to the current labor market in the environment instability and transformation in all social spheres. Thus, the aim set for the author's research was achieved and the role of summer schools in the process of developing leadership competencies and personal qualities among representatives of modern youth was substantiated. There were defined and fulfilled the following tusks in line with the research aim: there were considered theoretical aspects of summer schools as an educational tool; presented the most complete classification of summer schools on various grounds is presented; studied the programs of summer schools, including summer schools on the development of leadership skills; investigated the key aspects of the perception of the modern leader among representatives by the younger generation, etc. The results obtained in the course of this research can be applied in the organization of leadership summer schools and in further scientific and practical research on on this issue.

\section{References}

Baranova D, Borshcheva K (2016) Mezhdunarodnaya politekhnicheskaya letnyaya shkola "Civil engineering and design" 2015. Stroitel'stvo unikal'nyh zdanij i sooruzhenij.1:43-52

Bendas T, Psychology of leadership: a textbook and a set of practical exercises, $1^{\text {st }}$ edn. (Urite: Moscow, 2017), $370 \mathrm{p}$.

Bennis W, On Becoming a Leader, $1^{\text {st }}$ edn. (Addison Wesley: New York,1989), 202 p.

Bordean ON, Sonea A (2018) Student satisfaction and perceived skills: any link to employability? Entrepreneurship and Sustainability Issues 6(1): 356-370. doi: 10.9770/jesi.2018.6.1(22)

Cooper S, Brilliant Leader: What the Best Leaders Know, Do and Say, $1^{\text {st }}$ edn. (Pearson Prentice Hall, 2007), $208 \mathrm{p}$.

Goleman D, Boyatzis R, McKee A, Primal Leadership. Learning to Lead with Emotional Intellect, $1^{\text {st }}$ edn. (Harvard Business School Press: Boston, 2002), 301 p.

Hansen (2018) Hansen summer school official website. http://www.hansensummerinstitute.org/ Accessed 16 July 2018

Kashina M (2013) Letnyaya shkola molodyh uchyonyh kak innovacionnyj proekt sistemy RANHiGS. Nauchnye trudy Severo-Zapadnogo instituta upravleniya 3 (10):234-235.

Komarova N (2015) Letnie shkoly kak instrument internacionalizacii vuza. In: Obshchestvo, nauka, innovacii (NPK - 2015).Vserossijskaya ezhegodnaya nauchno-prakticheskaya konferenciya: Sbornik materialov: VPO "Vyatskij gosudarstvennyj universitet" 1:2498 -2500.

Krasnova G (2012) Letnie shkoly: tretij semestr ili obrazovatel'nyj turizm? Innovacii v obrazovanii 4:125-128.

Lazányi K, Čepel M, Bilan S (2017) Comparison of Trust and Social Relations among Students in Russian and Hungarian Higher Education. Economics and Sociology 10(4):162-174. doi:10.14254/2071-789X.2017/10-4/13

Mamedov R (2011) Mezhdunarodnye letnie shkoly: zarubezhnyj opyt. Pravo i Obrazovanie 12:39-43

Mann R (1959) A review of the Relationships between Personality and Performance in Small Groups. Psychologocal Bulletin 56(4):241-270. doi: 10.1037/h0044587

Naumkin N, Grosheva E, Kupryashkin V, Shekshaeva N, Panyushkina E (2012) Letnie nauchnye shkoly vazhnyj komponent podgotovki studentov nacional'nyh issledovatel'skih universitetov $\mathrm{k}$ innovacionnoj deyatel'nosti. Fundamental'nye issledovaniya 11(1):84-89.

Nazarova I (2017) Letnie shkoly universitetov: tekhnologii organizacii. Vysshee obrazovanie v Rossii 8(9):5763. 
Parfenova S (2015) Informacionnye tekhnologii v organizacii i provedenii letnih shkol v Rossii i Evrope.Vestnik Moskovskogo gorodskogo pedagogicheskogo universiteta. Seriya: Informatika i informatizaciya obrazovaniya 4 (34):77-82.

Schneider G (2017) Intercultural learning in summer schools. V sbornike: Ekonomicheskaya nauka hozyajstvennoj praktike Materialy XVIII Mezhdunarodnoj nauchno-prakticheskoj konferencii 2017:27-35.

Stogftll R, Handbook of Leadership, 1st edn. (The Free Press: New York, 1974), 576 p. 